УдК 340

\author{
Н.П. Харченко

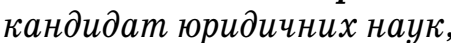 \\ старший викладач кафедри теорії держави та права \\ Національної акаделії внутрішніх справ
}

\title{
СТРУКТУРА ПРАВОВОГО РЕЖИМУ: ЗАГАЛЬНОТЕОРЕТИЧНА ХАРАКТЕРИСТИКА
}

Дослідження структури правового режиму $е$ важливим елементом комплексного та системного пізнання правового режиму як загальнотеоретичної конструкції. Адже характеристика будь-якого правового режиму розкривається винятково через окреслення особливостей тих и інших його елементів. Саме від вибору конкретних складових правового режиму здійснюються різні упорядковуючи впливи на конкретні суспільні відносини.

Як слушно зауважує М.З. Романюк: «На основі аналізу правового режиму як загальнотеоретичної категорії можна зробити висновок про те, що лише повна деталізація всіх його елементів у нормативно-правовому акті здатна надати йому стабільність, сприйнятливість із боку адресата, високу ефективність, забезпечити безперебійну роботу механізму правового регулювання. Відсутність основних структурних елементів правового режиму, що відповідають основним елементам правового регулювання, саме по собі перетворює правовий режим у недобудовану, неробочу конструкцію» [1].

Отже, пізнання такої важливої юридичної категорії як «правовий режим» неможливе без визначення складових елементів, що зумовлює не лише теоретичну, а й, насамперед, практичну актуальність цієї наукової розвідки.

Попри наявність численних вітчизняних нормативно-правових актах, у яких визначено особливості конкретного правового режиму, та чималої низки наукових досліджень загальнотеоретичного та галузевого характеру, нині предмет дослідження цієї статті залишається недостатньо розробленим.

«Окреслення окремих аспектів правового режиму дослідниками в наукових працях є доволі фрагментарним, що унеможливлюе сформувати єдине визначення поняття правового режиму, розкрити його зміст, особливості, структуру, види. Плюралізм загальнотеоретичних досліджень у цій сфері призводить до доволі дискусійного, а інколи й суперечливого застосування цієї категорії в галузевих розвідках" [2, с. 33 ; 3 , с. 26].

Вагоме значення у розумінні цієї проблематики мають загальнотеоретичні та галузеві напрацювання таких дослідників як: С.С. Алексєєв, Д.Н. Бахрах, С.В. Бобровник, С.Д. Гусарєв, А.М. Завальний, В.Б. Ісаков, В.В. Копєйчиков, А.В. Малько, Н.І. Матузов, П.М. Рабінович, І.О. Соколова, В.Д. Сорокін, О.Д. Тихомиров,
Л.В. Томаш, Л.С. Явич та деякі інші. Однак вони мають плюралістичний і фрагментарний характер.

Метою написання наукової статті є надання загальнотеоретичної характеристики структури правового режиму у вітчизняній юридичній доктрині та українській правовій системі.

Задля цього автором поставлені такі завдання:

- окреслити наукові позиції щодо визначення структури правового режиму;

- дослідити стан вітчизняного законодавства у цій сфері;

- надати авторське визначення структури правового режиму.

Однією із першою комплексною доктринальною працею у цій сфері стало дисертаційне дослідження I.O. Соколової, яка зауважила: «Ключовим для розгляду структури правового режиму $є$ поняття правових засобів. У широкому розумінні останні об'єднують у собі всі структурні елементи механізму правового регулювання: дозволи, рекомендації, норми, договори, правосуб'єктність, суб'єктивні права, юридичні обов'язки, правові заохочення та обмеження, юридичну відповідальність тощо. Структура правового режиму може розглядатися й у широкому соціальному контексті як така, що складається 3 трьох елементів: об'єкта-носія режиму, середовища, змісту. Обгрунтовується, що до структури правового режиму відносяться лише однорідні правові засоби, які складають його «юридичну формулу» - способи, методи й типи правового регулювання.

Способами правового регулювання є первинні засоби правового впливу на поведінку людей, пов'язані з наділенням їх суб'єктивними правами або покладанням на них юридичних обов'язків (дозвіл, заборона, зобов'язання). Наступним структурним елементом виступає метод правового регулювання - сукупність певних прийомів, способів, засобів впливу права на певну сферу суспільних відносин (імперативний, диспозитивний). Крім того, до структури правового режиму слід включити типи правового регулювання (загальнодозвільний, спеціальнодозвільний). У разі застосування як загальнодозвільного, так і спеціальнодозвільного типів правового регулювання законодавець використовує своєрідний юридично-технічний прийом, який полягає в установленні загального правила (принципу) - дозволу або заборони) з наступним установленням винятків з нього» [4, с. 9-10]. 
На думку ж С.К. Бадамшина, структура правового режиму включає такі елементи, як носій режиму, режимні правові засоби, режимні правила, правові статуси суб'єктів режимного регулювання, систему організаційно-юридичних гарантій [5, с. 56].

Конструктивною вбачається позиція Л.К. Терещенко, котра пропонує виокремлювати такі елементи правового режиму інформації:

- його цільове призначення;

- об'єкти правового регулювання;

- правове становище суб'єктів правового режима;

- комплекс способів правового регулювання і засобів юридичного впливу [6, с. 188].

Дослідження вітчизняних нормативно-правових актів, що визначають окремі види правових режимів, дозволяє також дійти висновку про плюралізм визначення структурних елементів правового режиму.

Уперше на нормативному рівні деякі аспекти структури правового режиму визначено у Договорі між Україною і Республікою Польща про правовий режим українсько-польського державного кордону, співробітництво та взаємну допомогу з прикордонних питань від 12 січня 1993 р. [7], ратифікованому Постановою Верховної Ради України «Про ратифікацію Договору між Україною і Республікою Польща про правовий режим українсько-польського державного кордону, співробітництво та взаємну допомогу з прикордонних питань» від 14 липня 1993 р. [8].

Зокрема закріплюється правила проходження, позначення і утримання кордону, суб'єкти забезпечення цих правил (Головні Прикордонні Уповноважені України і Республіки Польща), їх права і обов'язки, об'єкти правового режиму (прикордонні води з перетинаючими лінію кордону залізницями, шосейними дорогами, а також іншими комунікаційними спорудами господарська діяльність і навколишне середовище) й особливості їх забезпечення тощо.

Абсолютна інша структура застосовується в Угоді СНД про правовий режим інформаційних ресурсів Прикордонних військ держав-учасниць Співдружності Незалежних Держав від 25 листопада 1998 р. [9]. Зокрема визначено: «Правовий режим інформаційних ресурсів Прикордонних військ визначається як узгоджені норми, що встановлюють: а) право власності на інформацію, окремі документи і масиви документів в інформаційних системах; б) порядок документування інформації, надання документам юридичної сили i ïi підтвердження; в) категорії інформації за рівнем доступу до неї; г) мети і порядок захисту інформації; д) права суб'єктів, що беруть участь у міждержавному інформаційному обміні між прикордонними військами Сторін» [9].
Одним із перших внутрішніх нормативно-правових актів у цій сфері є Закон України «Про правовий режим території, що зазнала радіоактивного забруднення внаслідок Чорнобильської катастрофи» від 27 лютого 1991 р. [10]. Головною метою цього закону є усунення наслідків Чорнобильської катастрофи шляхом законодавчого визначення правового режиму різних за ступенем радіоактивного забруднення територій і заходів щодо його забезпечення. «Закон регулює питання поділу території на відповідні зони, режим їх використання та охорони, умови проживання та роботи населення, господарську, науково-дослідну та іншу діяльність в цих зонах, а також закріплює і гарантує забезпечення режиму використання та охорони вказаних територій з метою зменшення дії радіоактивного опромінення на здоров'я людини та на екологічні системи» [10].

Крім того, цей Закон визначає контроль за додержанням правового режиму в зонах, що зазнали радіоактивного забруднення внаслідок Чорнобильської катастрофи, та відповідальність за порушення правового режиму в зонах, які зазнали радіоактивного забруднення.

Надалі окремі аспекти структури правового режиму закріплено у Закон України «Про правовий режим майна, що забезпечує діяльність Верховної Ради України» від 17 квітня 1997 р. [11], який визначає порядок володіння, користування та розпорядження майном, що забезпечує діяльність Верховної Ради України. На жаль, цей нормативно-правовий акт містить лише чотири статті, де визначено доволі абстрактно правовий режим майна, що забезпечує діяльність Верховної Ради України. Тому виокремлення структурних елементів вищезазначеного режиму є неможливим.

Закон України «Про спеціальний режим інноваційної діяльності технологічних парків» від 16 липня 1999 р. закріплює правові та економічні засади запровадження та функціонування спеціального режиму інноваційної діяльності технологічних парків, а саме закріплено порядок експертизи, розгляду та державної реєстрації технологічного парку, контроль і відповідальність за реалізацію проектів технологічних парків тощо [12].

Надалі окремі аспекти структури правового режиму закріплено у Законі України «Про правовий режим майна у Збройних Силах України» від 21 вересня 1999 р., де визначено правовий режим майна, закріпленого за військовими частинами, закладами, установами та організаціями Збройних Сил України, і повноваження органів військового управління та посадових осіб щодо управління цим майном [13].

Зокрема нормативно визначено особливості статусу військового майна, а саме його обліку, інвентаризації, зберігання, списання, використання, відчуження, утилізації та передача військового 
майна тощо, повноваження органів військового управління та посадових осіб щодо управління цим майном, а також загальні засади відповідальності за порушення норм цього Закону.

У Законі України «Про правовий режим надзвичайного стану" від 16 березня 2000 р. [14] також нормативно закріплюється окремі елементи правового режиму, зокрема зміст правового режиму надзвичайного стану, порядок його введення та припинення дії, особливості діяльності органів державної влади й органів місцевого самоврядування, підприємств, установ і організацій в умовах надзвичайного стану, заходи правового режиму, що запроваджується, гарантії прав і свобод людини і громадянина, а також прав і законних інтересів юридичних осіб, участь представників інших держав у ліквідації наслідків надзвичайних ситуацій та відповідальність за порушення вимог або невиконання заходів правового режиму надзвичайного стану».

Не менш важливим для окреслення структури правового режиму є Закон України «Про забезпечення прав і свобод громадян і правовий режим на тимчасово окупованій території України» від 15 квітня 2014 р. [15], де закріплюються основи правового статусу тимчасово окупованої території України, заходи щодо захисту прав і свобод людини та громадянина, культурної спадщини на тимчасово окупованій території, заходи правового реагування на тимчасово окупованій території, особливості здійснення економічної діяльності на тимчасово окупованій території та припинення проходження громадянами України військової служби у військових формуваннях та правоохоронних органах України, пов'язані з тимчасовою окупацією території, зобов'язання державних органів України, гарантії прав і свобод громадян України, які виїхали за межі тимчасово окупованої території, відповідальність за порушення вимог цього Закону.

Одним із останніх законів, де визначено окремі елементи правового режиму, є нова редакція Закону України «Про правовий режим воєнного стану» від 12 травня 2015 р. [16]. Зокрема закріплено зміст правового режиму воєнного стану, порядок його введення та скасування, правові засади діяльності органів державної влади, військового командування, військових адміністрацій, органів місцевого самоврядування, підприємств, установ та організацій в умовах воєнного стану, гарантії законності та дотримання прав і свобод людини і громадянина та прав і законних інтересів юридичних осіб, відповідальність за порушення правового режиму воєнного стану, правосуддя в умовах воєнного стану тощо.

Практично ідентична структура правового режиму міститься також у Законах України «Про особливості правового режиму діяльності Національної академії наук України, національних галузевих академій наук та статусу ïх майнового комплексу» від 7 лютого 2002 р. [17],
«Про землі енергетики та правовий режим спеціальних зон енергетичних об'єктів» від 09 липня 2010 р. [18], «Про правовий режим земель охоронних зон об'єктів магістральних трубопроводів» від 17 лютого 2011 р. [19] тощо.

Отже, аналіз вітчизняних нормативно-правових актів, що визначають окремі види правових режимів, а також дослідження наукових позицій у цій сфері, дозволяє дійти таких висновків.

Основу будь-якого правового режиму складають нормативно-правові акти, що встановлюють особливий порядок діяльності у тих або інших сферах. Зокрема визначають:

- мету та завдання встановлення правового режиму;

- особливості правового статусу уповноважених державних органів, що спеціально створені або наділені повноваженнями формувати та підтримувати відповідний режим;

- особливості правового статусу органів місцевого самоврядування щодо підтримання відповідного режиму;

- регламентацію поведінки суб'єктів права та їх взаємовідносин;

- систему контролю та відповідальності у разі порушення відповідного правового режиму;

- спеціальні організаційні, технічні, матеріально-фінансові засоби забезпечення відповідного правового режиму.

\section{Jimepamypa}

1. Романюк М.З. Поняття та структура правового режиму земель. URL: http://www.nbpublish.com/library get_pdf.php?id=27309 (дата звернення: 29.05.2019).

2. Харченко Н.П. Правовий режим: окремі загальнотеоретичні аспекти. Науковий вісник Херсонського державного університету. Серія "Юридичні науки». 2016. Вип. 2. Т. 1. С. 32-35.

3. Харченко Н.П. Види правових режимів: плюралізм наукових підходів. Науково-практичний журнал «Прикарпатський юридичний вісник». 2018. Вип. 1 (22). C. 25-28.

4. Соколова I.О. Правовий режим: поняття, особливості, різновиди : автореф. дис. ... канд. юрид. наук : 12.00.01. Харків, 2004. 24 с.

5. Бадамшин С.К., Вагапова Л.Х. Определение структуры правового режима. Международный журнал социальных и гуманитарных наук. 2016. Т. 1. № 1. С. 54-57.

6. Терещенко Л.К. Правовой режим информации : дис. ... док. юрид. наук : 12.00 .14 . Москва, 2011. 415 с.

7. Договір між Україною і Республікою Польща про правовий режим українсько-польського державного кордону, співробітництво та взаємну допомогу з прикордонних питань від 12 січня 1993 p. URL: https://zakon.rada.gov.ua/laws/show/616_208 (дата звернення: 29.05.2019).

8. Про ратифікацію Договору між Україною і Республікою Польща про правовий режим українсько-польського державного кордону, співробітництво та взаємну допомогу з прикордонних питань : Постанова Верховної Ради України від 14 липня 1993 р. № 616. URL: https://zakon.rada.gov.ua/laws/show/616 208 (дата звернення: 29.05.2019). 
9. Угода СНД про правовий режим інформаційних ресурсів Прикордонних військ держав-учасниць Співдружності Незалежних Держав від 25 листопада 1998 p. URL: https://zakon.rada.gov.ua/laws/ show/997 344 (дата звернення: 29.05.2019).

10. Про правовий режим території, що зазнала радіоактивного забруднення внаслідок Чорнобильської катастрофи : Закон України від 27 лютого 1991 р. № 791. URL: https://zakon.rada.gov.ua/laws/show/ 791\% D0\% B0-12 (дата звернення: 29.05.2019).

11. Про правовий режим майна, що забезпечує діяльність Верховної Ради України : Закон України від 17 квітня 1997 р. № 594. URL: https://zakon.rada.gov.ua/ laws/show $/ 594 / 96$ - \% D0\% B2\% D1\% 80 (дата звернення: 29.05.2019).

12. Про спеціальний режим інноваційної діяльності технологічних парків : Закон України від 16 липня 1999 p. № 991. URL: https://zakon.rada.gov.ua/laws/ show/991-14 (дата звернення: 29.05.2019).

13. Про правовий режим майна у Збройних Силах України : Закон України від 21 вересня 1999 р. № 1075. URL: https://zakon.rada.gov.ua/laws/show/1075-14 (дата звернення: 29.05.2019).

14. Про правовий режим надзвичайного стану : Закон України від 16 березня 2000 р. № 1550. URL: https://zakon.rada.gov.ua/laws/show/1550-14 (дата звернення: 29.05.2019).

15. Про забезпечення прав і свобод громадян та правовий режим на тимчасово окупованій території України : Закон України від 15 квітня 2014 р. № 1207. URL: https://zakon.rada.gov.ua/laws/show/1207-vii (дата звернення: 29.05.2019).

16. Про правовий режим воєнного стану : Закон України від 12 травня 2015 р. № 389. URL: https://zakon.rada.gov.ua/laws/show/389-19 (дата звернення: 29.05.2019).

17. Про особливості правового режиму діяльності Національної академії наук України, національних галузевих академій наук та статусу їх майнового комплексу : Закон України від 07 лютого 2002 р. № 3065. URL: https://zakon.rada.gov.ua/laws/show/3065-14 (дата звернення: 29.05.2019).

18. Про землі енергетики та правовий режим спеціальних зон енергетичних об'єктів : Закон України від 09липня 2010p.№2480.URL:https://zakon.rada.gov.ua/ laws/show/2480-17 (дата звернення: 29.05.2019).

19. Про правовий режим земель охоронних зон об'єктів магістральних трубопроводів : Закон України від 17 лютого 2011 р. № 3041. URL: https://zakon.rada.gov.ua/laws/show/3041-17 (дата звернення: 29.05.2019).

\section{Анотація}

Харченко Н. П. Структура правового режиму: загальнотеоретична характеристика. - Стаття.

У статті акцентується на тому, що питання структури правового режиму є важливим елементом комплексного та системного пізнання правового режиму як загальнотеоретичної конструкції. Адже характеристика будь-якого правового режиму розкривається винятково через окреслення особливостей тих чи інших його елементів. Саме від вибору конкретних складових правового режиму здійснюються різні упорядковуючи впливи на конкретні суспільні відносини. Розглянуто структуру правового режиму, окреслено наукові пози- ції щодо виокремлення елементів правового режиму, особливості застосування цієї категорії у вітчизняному законодавстві, а також надано авторське бачення структури правового режиму. Дослідження вітчизняних нормативно-правових актів, які визначають окремі види правових режимів, уможливило дійти висновку про правову неунормованість структурних елементів правового режиму. Висновується, що структура правового режиму доволі поверхнево окреслюється в загальнотеоретичних доктринальних працях. Натомість бачення цієї проблематики в галузевих наукових розробках у цій сфері є доволі плюралістичним.

Констатовано, що основу будь-якого правового режиму складають нормативно-правові акти, які встановлюють особливий порядок діяльності у тих або інших сферах, що проявляється через мету та завдання встановлення правового режиму, особливості правового статусу уповноважених державних органів, що спеціально створені або наділені повноваженнями формувати та підтримувати відповідний режим або органів місцевого самоврядування; регламентацію поведінки суб'єктів права та їх взаємовідносин; систему контролю та відповідальності у разі порушення відповідного правового режиму та спеціальні організаційні, технічні, матеріально-фінансові засоби забезпечення відповідного правового режиму.

Ключові слова: режим, правовий режим, структура правового режиму, елементи структури правового режиму

\section{Summary}

Kharchenko N.P. The structure of legal regimes: the general theoretical characteristic. - Article.

The article emphasizes that the question of the structure of the legal regime is an important element of the complex and systematic knowledge of the legal regime as a general theoretical construction. After all, the characterization of any legal regime is revealed solely because of the delineation of the features of those and other elements of it. It is from the choice of specific components of the legal regime that various ordering influences on specific social relations are carried out. The structure of the legal regime is considered, the scientific positions regarding the distinguishing elements of the legal regime, the peculiarities of the use of this category in the domestic legislation are outlined, as well as the author's vision of the structure of the legal regime. The study of domestic normative legal acts, which determine certain types of legal regimes, made it possible to conclude that the legal structure of the legal regime is legal in nature. Instead, the vision of this issue in sectoral research in this area is rather pluralistic. It is stated that the basis of any legal regime is the normative legal acts that establish a special procedure of activity in those or other spheres, which finds its manifestation through the purpose and tasks of establishing a legal regime, especially the legal status of authorized state bodies that are specially created or endowed the authority to form and maintain an appropriate regime or local self-government bodies; regulation of the behavior of subjects of law and their relationship; a system of control and liability in case of violation of the relevant legal regime and special organizational, technical, material and financial means of providing the appropriate legal regime.

Key words: regime, legal regime, structure of the legal regime, elements of the structure of the legal regime. 